Article

\title{
Tri-Herbal Medicine Divya Sarva-Kalp-Kwath (Livogrit) Regulates Fatty Acid-Induced Steatosis in Human HepG2 Cells through Inhibition of Intracellular Triglycerides and Extracellular Glycerol Levels
}

\author{
Acharya Balkrishna ${ }^{1,2,3}$, Vivek Gohel ${ }^{1}$, Rani Singh ${ }^{1}$, Monali Joshi ${ }^{1}$, Yash Varshney ${ }^{1}$, \\ Jyotish Srivastava ${ }^{1}$, Kunal Bhattacharya ${ }^{1}$ and Anurag Varshney ${ }^{1,2, *(D)}$ \\ 1 Drug Discovery and Development Division, Patanjali Research Institute, \\ Governed by Patanjali Research Foundation Trust, NH-58, Haridwar 249 405, Uttarakhand, India \\ 2 Department of Allied and Applied Sciences, University of Patanjali, Patanjali Yog Peeth, \\ Roorkee-Haridwar Road, Haridwar 249 405, Uttarakhand, India \\ 3 Patanjali Yog Peeth (UK) Trust, 40 Lambhill Street, Kinning Park, Glasgow G41 1AU, UK \\ * Correspondence: anurag@prft.co.in; Tel.: +91-1334-244-107 (ext. x7458); Fax: +91-1334-244-805
}

Academic Editor: Michal Tomczyk

Received: 14 September 2020; Accepted: 13 October 2020; Published: 21 October 2020

\begin{abstract}
Steatosis is characterized by excessive triglycerides accumulation in liver cells. Recently, application of herbal formulations has gained importance in treating complex diseases. Therefore, this study explores the efficacy of tri-herbal medicine Divya Sarva-Kalp-Kwath (SKK; brand name, Livogrit) in treating free fatty acid (FFA)-induced steatosis in human liver (HepG2) cells and rat primary hepatocytes. Previously, we demonstrated that cytosafe SKK ameliorated $\mathrm{CCl}_{4}$-induced hepatotoxicity. In this study, we evaluated the role of SKK in reducing FFA-induced cell-death, and steatosis in HepG2 through analysis of cell viability, intracellular lipid and triglyceride accumulation, extracellular free glycerol levels, and mRNA expression changes. Plant metabolic components fingerprinting in SKK was performed via High Performance Thin Layer Chromatography (HPTLC). Treatment with SKK significantly reduced the loss of cell viability induced by $2 \mathrm{mM}$-FFA in a dose-dependent manner. SKK also reduced intracellular lipid, triglyceride accumulation, secreted AST levels, and increased extracellular free glycerol presence in the FFA-exposed cells. SKK normalized the FFA-stimulated overexpression of SREBP1c, FAS, C/EBP $\alpha$, and CPT1A genes associated with the induction of steatosis. In addition, treatment of rat primary hepatocytes with FFA and SKK concurrently, reduced intracellular lipid accumulation. Thus, SKK showed efficacy in reducing intracellular triglyceride accumulation and increasing extracellular glycerol release, along with downregulation of related key genetic factors for FFA-associated steatosis.
\end{abstract}

Keywords: steatosis; hepatocytes; Ayurveda; Phyto-medicines; Sarva-Kalp-Kwath; Livogrit; HepG2 cells

\section{Introduction}

Liver ailments are evolving rapidly due to modern sedentary lifestyle, food-habits, and dependence on medications for minor illnesses. Liver steatosis is prevalent in the majority of obese individuals and the most common pathological condition found in 33\% of the adult population in the United States of America [1]. Development of steatosis often originates from high-fat diet intake and metabolic disorders leading to excessive deposition of lipids and triglycerides (TGs) in the hepatocytes of patients [2,3]. Free fatty acids (FFAs) in the diet also increase levels of ceramides, which are known to be involved in 
several pathways linked to inflammation, apoptosis, insulin resistance, oxidative stress, and progression of steatosis [4]. Prolonged persistence of steatosis may lead to the development of hepatic fibrosis and other non-hepatic (cardiovascular, cancer, and neurological) health complications. While the global prevalence of non-alcoholic fatty liver disease might be near to a billion cases, the prevailing variety in the pathological manifestation of steatosis disease leads it to be rather under-reported [5]. Palmitic acid and monounsaturated oleic acid represents the two most abundant FFA present in high-fat diets [6]. Intake of high levels of oleic acid and palmitic acids from food sources has been shown to induce steatosis in hepatocytes of different organisms [7-14].

Triglycerides are synthesized in the hepatic region from FFA and glycerol molecules. The process of triglyceride formation is regulated by several transcriptional factors such as sterol regulatory element-binding protein 1 (SREBP1c), and CCAAT/enhancer-binding protein- $\alpha(\mathrm{C} / \mathrm{EBP} \alpha)$, which are expressed in the hepatocytes and modulate the expression of downstream genes like fatty acid synthase (FAS), responsible for fatty acid synthesis [15]. Effective diversion of the intracellular FFA towards the mitochondrial beta-oxidation process is the task of carnitine palmitoyltransferase 1A (CPT1A) [16]. For retaining normoglycemic conditions, the liver tends to metabolize excess glucose to FFA through the process of de novo lipogenesis involving activation of transcriptional factors and lipogenic genes [17]. This FFA accounts for $26 \%$ of total stored triglycerides in hepatocytes [17]. Herbal formulations have been observed to inhibit triglyceride formation through SREBP1c and C/EBP $\alpha$ pathways inducing lipolysis and subsequent glycerol release $[15,18]$.

Tri-herbal decoction of Divya Sarva-Kalp-Kwath (SKK) is being used in Ayurveda for treating a plethora of liver-related ailments and is being marketed under the brand name 'Livogrit'. SKK is prepared by combining the aqueous extracts obtained from plants identified by Council of Scientific and Industrial Research-National Institute of Science Communication and Information Resources (CSIR-NISCAIR), Delhi, India as Boerhavia diffusa L. (Nyctaginaceae) (NISCAIR/RHMD/Consult/2019/3453-54-149), P. niruri sensu Hook. f. (Euphorbiaceae) (NISCAIR/RHMD/Consult/2019/3453-54-30), and Solanum nigrum L. (Solanaceae) (NISCAIR/RHMD/Consult/2019/3453-54-119) plants in the ratio of 2:1:1. B. diffusa L. plant also known as "Punarnava" possesses a variety of isoflavonoids such as rotenoids, flavonoids, flavonoid glycosides, xanthones, lignans, ecdysteroids, and steroids [19]. These plant metabolites have been found to have hepatoprotective effects. For example, B. diffusa L. plant extract can modulate liver injury in animals through a reduction of cytochrome enzyme activities [20]. P. niruri sensu Hook. f. also known as "Bhumi amalaki" contains metabolites such as, alkaloids, anthocyanins, chlorogenic acids, flavonoids, lignans, phenolic acids, tannins, terpenoids, and saponins that attribute to its bioactivity [21-26]. S. nigrum L. also known as "Makoy" contains several steroidal glycosides, steroidal alkaloids and steroidal oligoglycosides that also act as antioxidants reducing hepatic injuries through amelioration of oxidative stress $[27,28]$. In our previous study, we performed a detailed chemical analysis of SKK by High Performance Liquid Chromatography and Liquid Chromatography based-Mass Spectroscopy. We have reported the presence of plant metabolites: gallic acid, caffeic acid, rutin, quercetin, catechin, and corilagin as marker components originating from its herbal components [19]. We have shown that SKK exhibited hepatoprotective effect in Wistar rats and HepG2 cells against Carbon Tetrachloride $\left(\mathrm{CCl}_{4}\right)$ induced toxicity and inflammation [19].

In this study, we examined the efficacy of SKK in modulating FFA-induced cell-death and steatosis in human HepG2 cells and rat primary hepatocytes. Validation for the presence of plant metabolic components in SKK was performed using the High Performance Thin Layer Chromatography (HPTLC) method through fingerprinting of plant metabolites. Steatosis was induced in HepG2 cells and rat primary hepatocytes grown in high glucose content cell-culture media using a combination of oleic acid and palmitic acid (FFA). The onset of cell-death and steatosis by FFA in the HepG2 cells and rat primary hepatocytes and its modulation by SKK were studied through parameters such as cell viability, intracellular lipids, triglyceride accumulation, extracellular free glycerol presence, and release of liver injury biomarker aspartate aminotransferase (AST) levels. At the genetic level, $\mathrm{C} / \mathrm{EBP} \alpha, \mathrm{SREBP} 1 \mathrm{c}$, 
FAS, and CPT1A mRNA expression changes induced by FFA and the ability of SKK in ameliorating these were studied in FFA induced and SKK-treated HepG2 cells.

\section{Results}

\subsection{HPTLC Fingerprinting of Divya Sarva-Kalp-Kwath (SKK)}

Preliminary screening of SKK for plant metabolites was performed using the HPTLC method (Figure 1). Results showed the presence of polyphenols namely gallic acid, caffeic acid, quercetin, catechin, rutin, and corilagin. These plant metabolites have also been identified using liquid chromatography-based mass spectroscopy (LC-MS) and high-performance liquid chromatography (HPLC) techniques in our previously published study [19]. Chromatogram analysis showed all plant metabolites of SKK were well separated without any tail or diffuseness (Figure 1A-D). Maximum retention factor $\left(R_{f}\right)$ values obtained for the different plant metabolite marker compounds weregallic acid: 0.62 (Figure $1 \mathrm{~A}$, spectra $\mathrm{A}, \mathrm{C}_{1}, \mathrm{C}_{2}$; Figure $1 \mathrm{~B}$, bands $\mathrm{A}, \mathrm{C}_{1}$, and $\mathrm{C}_{2}$ ), caffeic acid: 0.74 (Figure $1 \mathrm{~A}$, spectra $\mathrm{B}, \mathrm{C}_{1}, \mathrm{C}_{2}$; Figure $1 \mathrm{~B}$, bands $\mathrm{B}, \mathrm{C}_{1}$, and $\mathrm{C}_{2}$ ), quercetin: 0.81 (Figure $1 \mathrm{~A}$, spectra $D, C_{1}, C_{2}$; Figure $1 B$, bands $D, C_{1}$ and $C_{2}$ ), catechin: 0.75 (Figure $1 C$, spectra $E, G_{1}, G_{2}$; Figure $1 D$, bands $E, G_{1}$, and $G_{2}$ ), rutin: 0.24 (Figure $1 C$, spectra $F, G_{1}, G_{2}$; Figure $1 D$, bands $F, G_{1}$, and $G_{2}$ ), and corilagin: 0.34 (Figure $1 C$, spectra $H, G_{1}, G_{2}$; Figure $1 D$, bands $H, G_{1}$ and $G_{2}$ ). No band intensity or position variations were observed in both replicates of SKK showing the robustness of the plant metabolites. The amount of total polyphenols present in SKK, obtained using the Folin-Ciocalteu method was $4.22 \% w / w$. Based upon HPTLC fingerprinting and phenolic content analysis, we reaffirmed the chemical constituents of SKK.
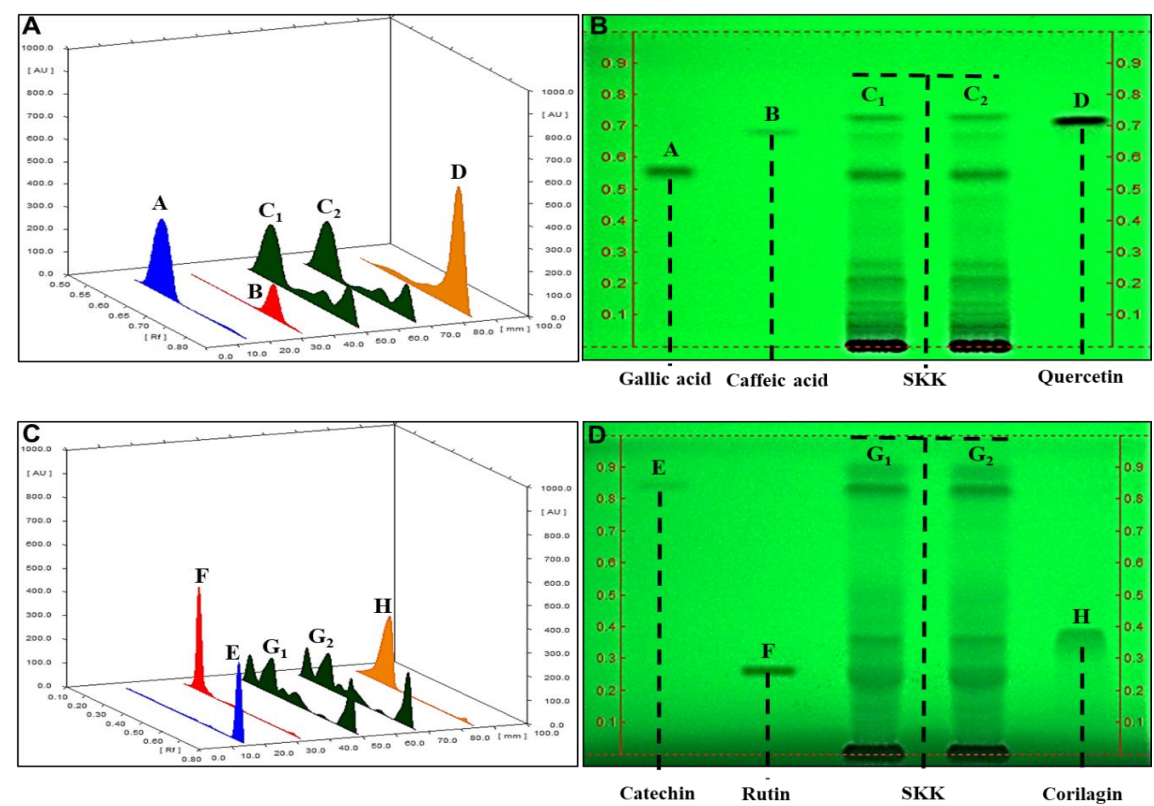

Figure 1. Chromatograms of Sarva-Kalp-Kwath (SKK) extract in the High Performance Thin Layer Chromatography (HPTLC) analysis. Chemical constituent analysis of SKK using HPTLC showed (A) comparative fingerprint analysis at $280 \mathrm{~nm}$ of $\left(\mathrm{C}_{1}, \mathrm{C}_{2}\right)$ SKK with (A) gallic acid, (B) caffeic acid, and (D) quercetin markers. (B) Corresponding comparative HPTLC image at $254 \mathrm{~nm}$ of $\left(\mathrm{C}_{1}, \mathrm{C}_{2}\right)$ SKK with (A) gallic acid, (B) caffeic acid, and (D) quercetin markers. (C) Comparative fingerprint at $280 \mathrm{~nm}$ of $\left(G_{1}, G_{2}\right)$ SKK with $(E)$ catechin, $(F)$ rutin, and $(H)$ corilagin markers. (D) Corresponding comparative HPTLC image at $254 \mathrm{~nm}$ of $\left(G_{1}, G_{2}\right)$ SKK with $(E)$ catechin, $(F)$ rutin, and $(H)$ corilagin markers. Results are displayed as 3D-overlaid spectra of SKK and marker compounds and their respective HPTLC chromatograms. 


\subsection{SKK Modulates HepG2 Cell Viability}

Preliminary cell viability screening of the SKK alone in HepG2 cells showed it to be safe up to the tested concentration of $100 \mu \mathrm{g} / \mathrm{mL}$. The half-maximal inhibitory concentration ( $\mathrm{IC}_{50}$ ) for SKK was calculated at $2801 \mu \mathrm{g} / \mathrm{mL}$ (Figure 2A). Exposure of HepG2 cells to $2 \mathrm{mM}$ FFA (oleic acid (O): $1.32 \mathrm{mM}$ and palmitic acid $(\mathrm{P}): 0.66 \mathrm{mM})$ induced a significant $(p$ value $<0.05)$ loss of cell viability $(70.3 \% \pm 5.1 \%)$ after $48 \mathrm{~h}$ treatment (Figure 2B). Pretreatment of HepG2 cells with varying concentrations of SKK showed a significant $(10 \mu \mathrm{g} / \mathrm{mL}$ : $p$ value $<0.05$ and $30 \mu \mathrm{g} / \mathrm{mL}$ : $p$ value $<0.001)$ dose-dependent hepatoprotective effect against the induction of cell-death by FFA (Figure 2B). These preliminary results indicated a protective role for SKK against FFA-induced toxicity without inducing any other observable side effects like a decrease in cell viability or metabolic impairment.

A

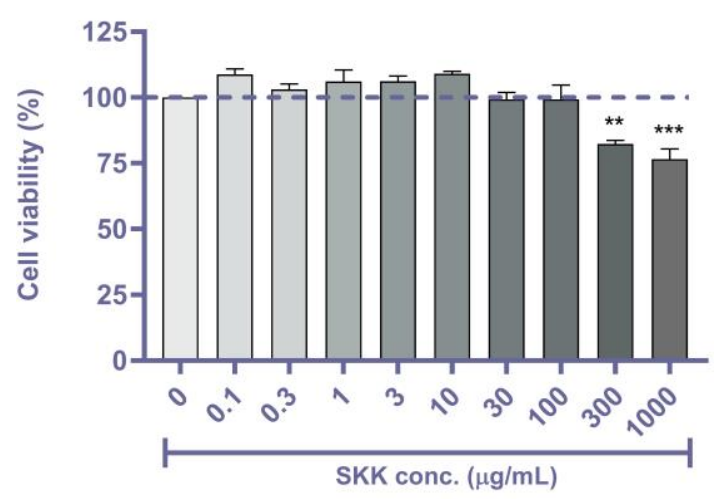

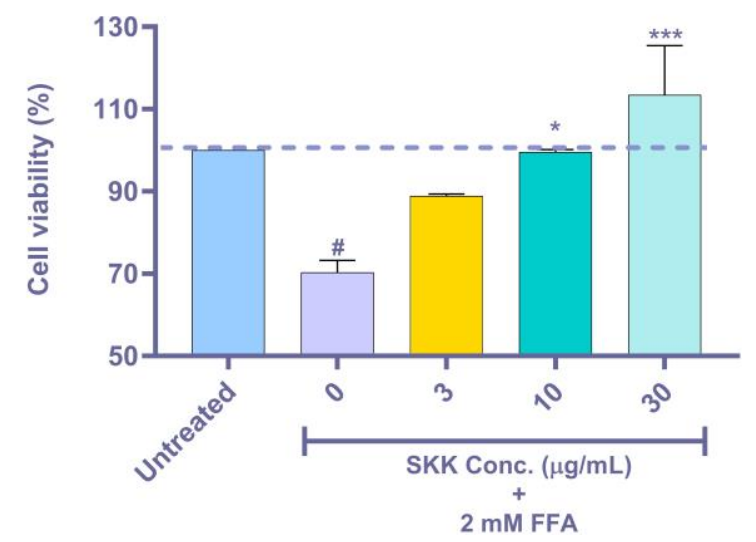

Figure 2. Effect of SKK on HepG2 cell viability. (A) Cytosafety profiling of HepG2 cells post-SKK $(0-1000 \mu \mathrm{g} / \mathrm{mL}$ ) treatment. (B) Cell viability analysis of free fatty acid (FFA)-treated HepG2 cells post-SKK $(0,3,10$, and $30 \mu \mathrm{g} / \mathrm{mL})$ treatment. All the experiment was performed thrice in triplicate and the results are displayed as mean \pm SEM. For statistical analysis, one-way ANOVA with Dunnett's multiple comparisons was done, wherein A) SKK doses vs. $0 \mu \mathrm{g} / \mathrm{mL} * * p$ value $<0.01$ and ${ }^{* * *} p$ value $<0.001$ and in $(\mathbf{B})$ untreated control vs. $0 \mu \mathrm{g} / \mathrm{mL}=\# p$ value $<0.05$, and SKK test concentrations vs. $0 \mu \mathrm{g} / \mathrm{mL}={ }^{*} p$ value $<0.05$ and ${ }^{* * *} p$ value $<0.001$.

\subsection{SKK Inhibits Intracellular Lipid Accumulation}

Treatment of HepG2 cells with varying combinations of oleic acid and palmitic acid showed significant ( $p$ value $<0.001)$ intracellular accumulation of lipids $(2.70 \pm 0.33$ fold $)$ at the $2 \mathrm{mM} \mathrm{FFA}$, as compared to the untreated cells (Figure $3 \mathrm{~A}$ ). This was measured using neutral lipid-binding oil red ' $\mathrm{O}$ ' (ORO) dye. Other combinations of oleic acid and palmitic acid did not induce any sizable changes in intracellular lipid accumulation in HepG2 cells (Figure 3A). Qualitative analysis of lipid accumulation in the HepG2 using ORO dye showed that cells treated with varying doses of SKK up to the highest therapeutic dose did not show any change in intracellular lipid accumulation compared to the normal control (Figure 3Bi,ii). However, cells treated with 2 mM FFA showed a significant increase in the intracellular lipid accumulation indicating the onset of steatosis (as seen in Figure 3Biii). Pretreatment of the HepG2 cells with varying concentrations of SKK $(3,10$, and $30 \mu \mathrm{g} / \mathrm{mL})$ considerably reduced the FFA-induced accumulation of intracellular lipids in the cells (Figure 3Biv,v,vi). Quantitative measurement of the ORO dye accumulation using a multiplate reader confirmed the visual observations (Figure 3B,C). Results showed that pretreatment of HepG2 cells with SKK $(0,3,10$, and $30 \mu \mathrm{g} / \mathrm{mL}$ ) significantly ( $p$ value $<0.01$ ) reduced the $2 \mathrm{mM}$ FFA-induced lipid accumulation in the HepG2 cells (Figure 3C). Interestingly, SKK showed similar effects in reducing FFA-stimulated intracellular lipid accumulation at all the tested concentrations. 
A

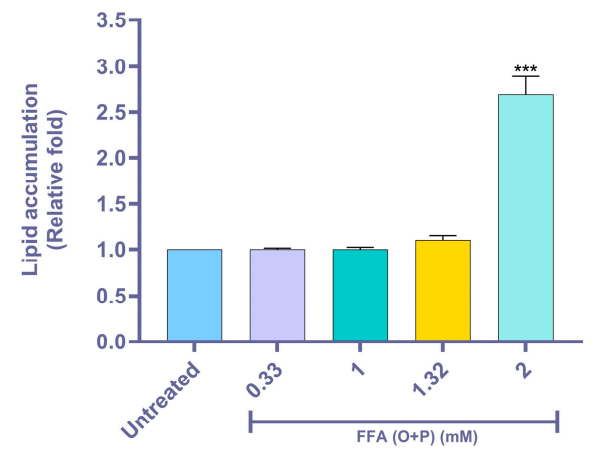

B
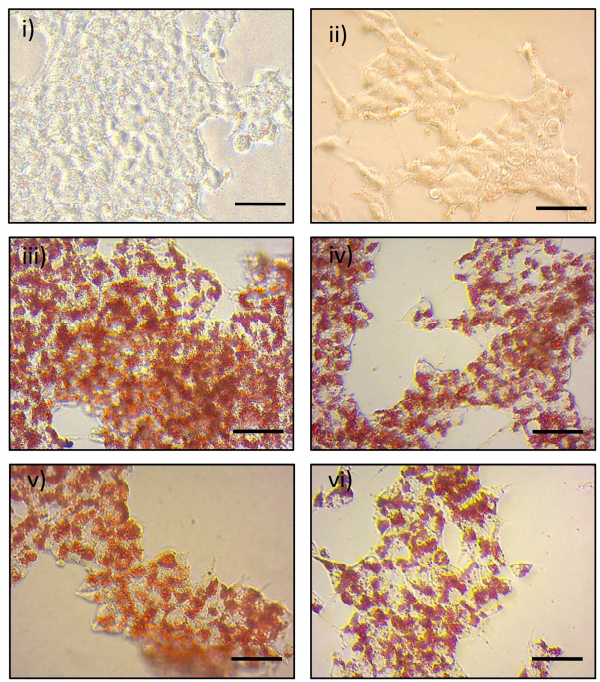

C

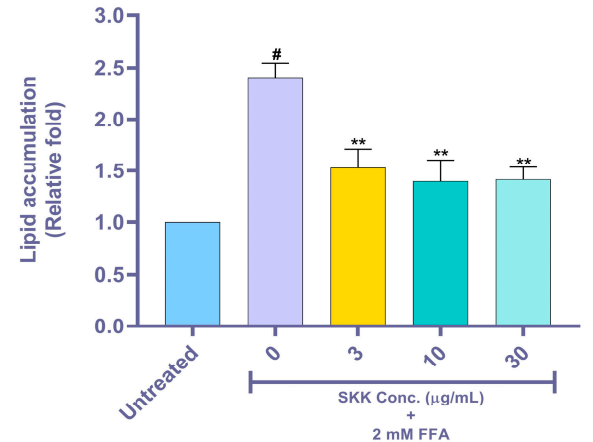

Figure 3. Intracellular lipid accumulation and its amelioration by SKK. (A) Intercellular lipid accumulation was evaluated in HepG2 cells following treatment with varying combinations of oleic acid $(\mathrm{O})$ and palmitic acid (P). (B) Visual analysis for oil red ' $\mathrm{O}$ ” dye accumulation associated with neutral lipids was performed in the HepG2 cells following pretreatment with SKK $(0,3,10$, and $30 \mu \mathrm{g} / \mathrm{mL})$ for $24 \mathrm{~h}$, and thereafter a combined treatment of SKK $(0,3,10$, and $30 \mu \mathrm{g} / \mathrm{mL})$, and $2 \mathrm{mM}$ FFA for $48 \mathrm{~h}$. The scale bar in the images represents $20 \mu \mathrm{m}$. (C) ORO staining results showed that SKK pretreatment inhibited the intracellular lipid accumulation stimulated by FFA exposure in the HepG2 cells. All the experiments were performed thrice in triplicate and the results are displayed as mean \pm SEM. For statistical analysis, one-way ANOVA with Dunnett's multiple comparisons was done, where untreated vs. FFA $={ }^{* * *} p$ value $<0.001$, untreated control vs. $0 \mu \mathrm{g} / \mathrm{mL}=\# p$ value $<0.001$, and SKK test concentrations vs. $0 \mu \mathrm{g} / \mathrm{mL}={ }^{* *} p$ value $<0.01$. 


\subsection{SKK Moderates Aspartate Aminotransferase (AST) Release, Intracellular Triglyceride, and Extracellular Glycerol Levels}

Aspartate aminotransferase (AST) is present as cytosolic and mitochondrial isoenzyme in the liver. However, during the occurrence of hepatic steatosis, high concentrations of AST are released and can be used as a biomarker of liver injury [29]. In our study, a significant ( $p$ value $<0.05$ ) increase in levels of AST levels was observed in HepG2 cells treated with 2 mM FFA ( $2.5 \pm 0.2$ fold) compared to untreated controls (Figure 4A). This FFA stimulated increase in AST level was significantly $(p$ value $<0.05)$ reduced to normal levels upon treatment with $30 \mu \mathrm{g} / \mathrm{mL}$ of SKK (Figure 4A). The intracellular triglyceride synthesis requires three molecules of FFA and one molecule of glycerol [30]. Hence, the induction of steatosis in the hepatocytes is accompanied by intracellular increase in triglyceride levels and reduced extracellular levels of free glycerol molecules. HepG2 cells treated with 2 mM FFA showed a significant $(p$ value $<0.05$ ) increase in the intracellular storage of triglycerides levels $(157.5 \pm 49.9 \mu \mathrm{g} / \mathrm{mg})$ compared to untreated cells (Figure 4A). Pretreatment of HepG2 cells with varying concentrations of SKK $(0,3,10$, and $30 \mu \mathrm{g} / \mathrm{mL})$ significantly reduced the intracellular accumulation of triglycerides $(52.85 \pm 15.6 \mu \mathrm{g} / \mathrm{mg})$ stimulated by FFA exposure (Figure 4B). Quantification of the free glycerol levels in the cell culture media, using the GC-MS method showed a significant reduction in the presence of glycerol levels in the FFA-treated HepG2 cell culture media, compared to media obtained from untreated cells, as per the area under the curve (AUC; Figure 4Ci,ii). Normalization of the glycerol contents based on individual sample protein content showed the presence of $53.07 \pm 11.5 \mu \mathrm{g}$ glycerol per mg protein in the cell culture media obtained from untreated cells. This glycerol level was reduced to $22.8 \pm 4.4 \mu \mathrm{g}$ per $\mathrm{mg}$ protein in the cell culture media obtained from $2 \mathrm{mM}$ FFA-treated HepG2 (Figure 4Ci,ii). This represented a $0.47 \pm 0.19$-fold change in extracellular glycerol content (Figure 4D). Pretreatment of HepG2 cells with varying concentrations of SKK $(0-30 \mu \mathrm{g} / \mathrm{mL})$ significantly recovered the extracellular levels of free glycerol molecules compared to FFA exposed cells (Figure 4Ciii,iv, v,D). The results showed modulation of liver injury and lipolysis process by SKK in the hepatocytes stimulated with high FFA exposure.

\subsection{Genomic Level Changes Induced by SKK in the In Vitro Steatosis Model}

Transcription factors, fatty acid synthase, and fatty acid transporter genes play a major role in the process of FFA metabolism, triglyceride synthesis, and induction of steatosis. Treatment of HepG2 cells with $2 \mathrm{mM}$ FFA induced the overexpression of steatosis associated C/EBP $\alpha$ (untreated cells (UC): $1.24 \pm 0.82 ; 0 \mu \mathrm{g} / \mathrm{mL}: 9.91 \pm 0.88)$, FAS (UC: $1.34 \pm 0.94 ; 0 \mu \mathrm{g} / \mathrm{mL}: 4.1 \pm 0.48)$, SREBP1c (UC: $0.61 \pm 0.19$; $0 \mu \mathrm{g} / \mathrm{mL}: 1.84 \pm 0.53$ ), and CPT1A (UC: $1.17 \pm 0.64 ; 0 \mu \mathrm{g} / \mathrm{mL}: 5.43 \pm 0.56$; Figure 5A-D). Pretreatment of HepG2 cells with varying doses of SKK significantly ameliorated the FFA-stimulated expressions of C/EBP $\alpha$, FAS, SREBP1c, and CPT1A (Figure 5A-D). However, SKK treatments did not exhibit a concentration-dependent effect. Heat-map analysis of the mRNA expression showed 2 mM FFA categorically stimulated an increase in mRNA expression levels of C/EBP $\alpha>C P T 1 A>$ FAS $>$ SREPB1c (Figure 5E). All the FFA-stimulated mRNA expressions were back to normal levels in HepG2 cells following prophylactic treatment with SKK.

\subsection{Intracellular Lipid Accumulation in the FFA Stimulated Rat Primary Hepatocytes}

Validation of SKK's efficacy in decreasing intracellular lipid accumulation was performed ex vivo on primary rat hepatocytes. Before analysis, a function evaluation of isolated primary hepatocytes was performed through albumin production assay. The freshly isolated rat primary hepatocytes were observed to produce $13.6 \pm 0.17 \mathrm{mg} / \mathrm{mL}$ of albumin, following a $24 \mathrm{~h}$ ex vivo culture. Short-term $(12 \mathrm{~h})$ concurrent exposure of freshly isolated primary Wistar rat hepatocytes to $2 \mathrm{mM}$ FFA showed a significant increase in the intracellular lipid accumulation (1.50 $\pm 0.01 \mathrm{fold})$ compared to untreated cells, measured using ORO dye (Figure 6). Concurrent treatment of the primary hepatocytes with SKK provided significant protection against FFA induced intracellular lipid accumulations leading to normalization of the intracellular lipid contents (Figure 6). 
A

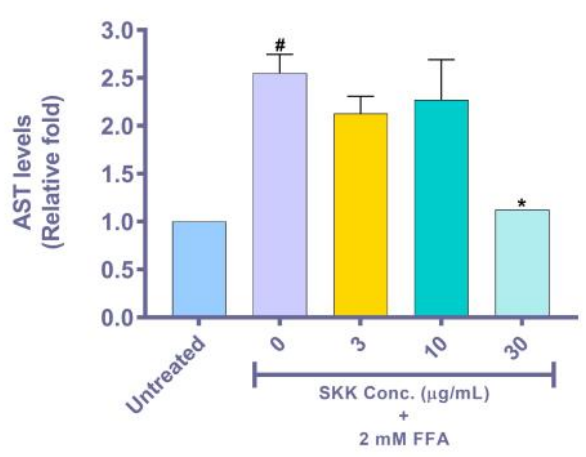

C
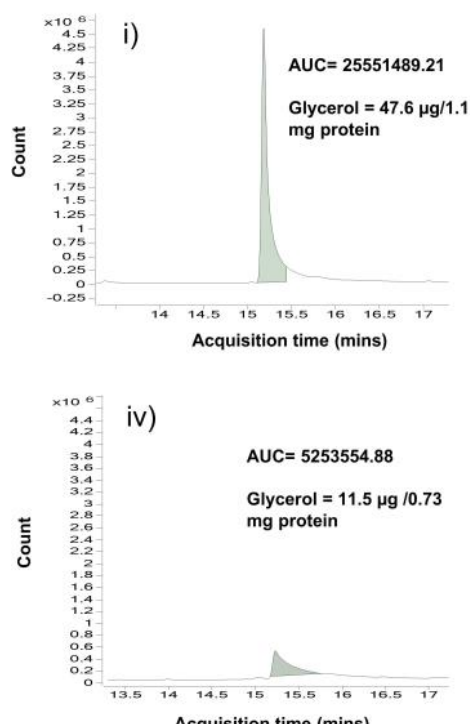

Acquisition time (mins)
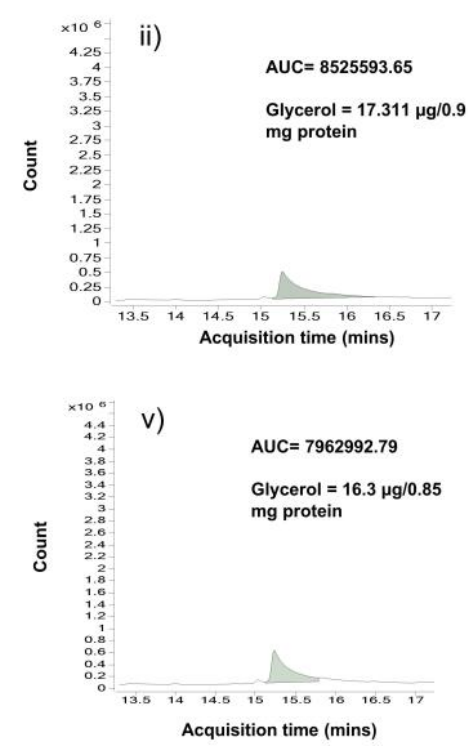

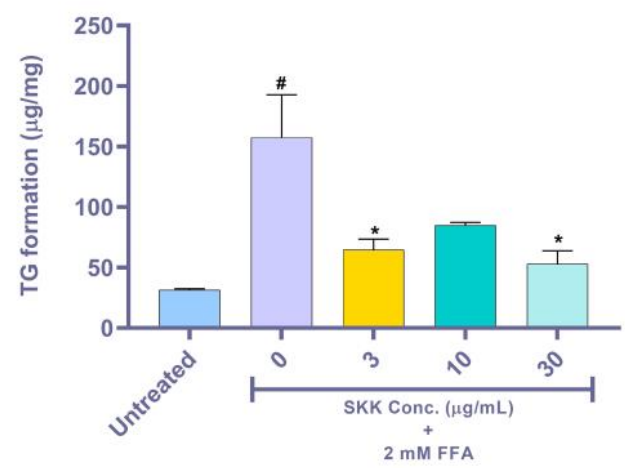

Figure 4. Quantification of intracellular triglyceride and extracellular glycerol release. (A) AST levels and (B) triglyceride accumulation, in HepG2 following treatment with SKK $(0,3,10$, and $30 \mu \mathrm{g} / \mathrm{mL})$. (C) The area under the curve (AUC) measurements obtained from the GC-MS analysis of the cell culture media for the presence of free glycerol. Spectra represents the presence of glycerol in cell culture media obtained from Untreated cells (i), 2 mM FFA-stimulated HepG2 cells (ii), HepG2 cells pretreated with $3 \mu \mathrm{g} / \mathrm{mL}$ SKK (iii), $10 \mu \mathrm{g} / \mathrm{mL}$ SKK (iv), and $30 \mu \mathrm{g} / \mathrm{mL}$ SKK (v) followed by $2 \mathrm{mM}$ FFA and SKK (respected concentration) for $48 \mathrm{~h}$. The representative spectra show AUC representing the presence of free glycerol molecules in the cell culture media. (D) Relative fold changes measured in the quantity of free glycerol levels present in the cell culture media obtained from untreated, FFA-treated, and SKK pretreated and FFA and SKK cotreated cells, normalized with individual protein levels in each sample. All the experiments were performed thrice in triplicate, and samples were pooled into 3 biological replicate groups for analysis purposes. Results are displayed as mean \pm SEM. For statistical analysis, one-way ANOVA with Dunnett's multiple comparisons was performed, where untreated control vs. $0 \mu \mathrm{g} / \mathrm{mL}=\# p$ value $<0.001$ and SKK test concentrations vs. $0 \mu \mathrm{g} / \mathrm{mL}={ }^{*} p$ value $<0.05$. 
A

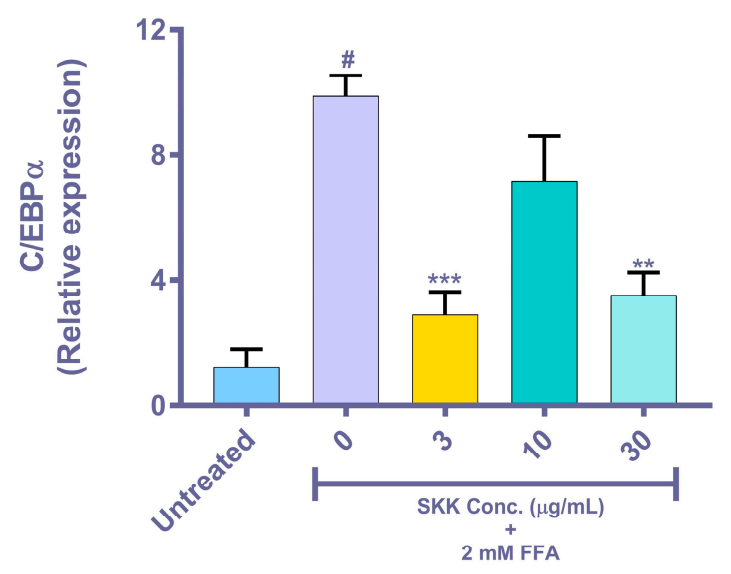

C

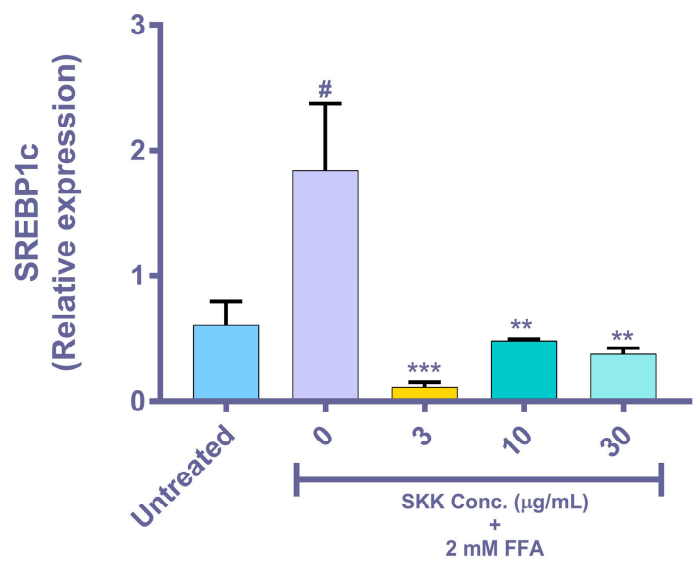

B

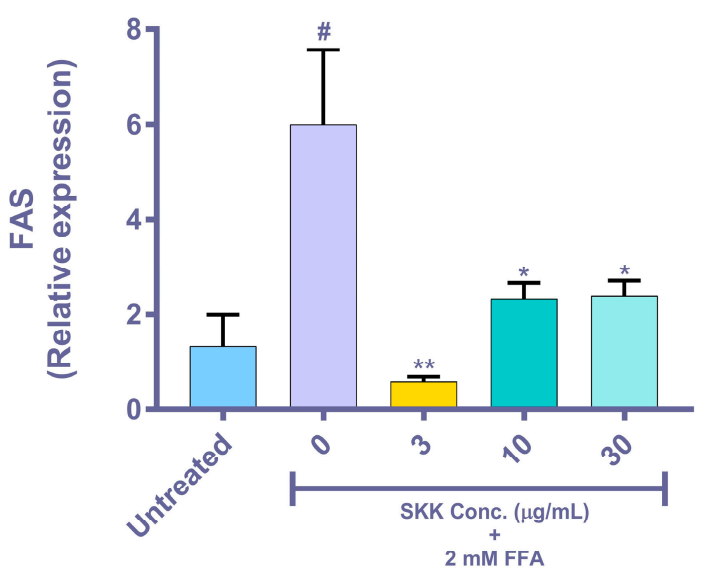

D

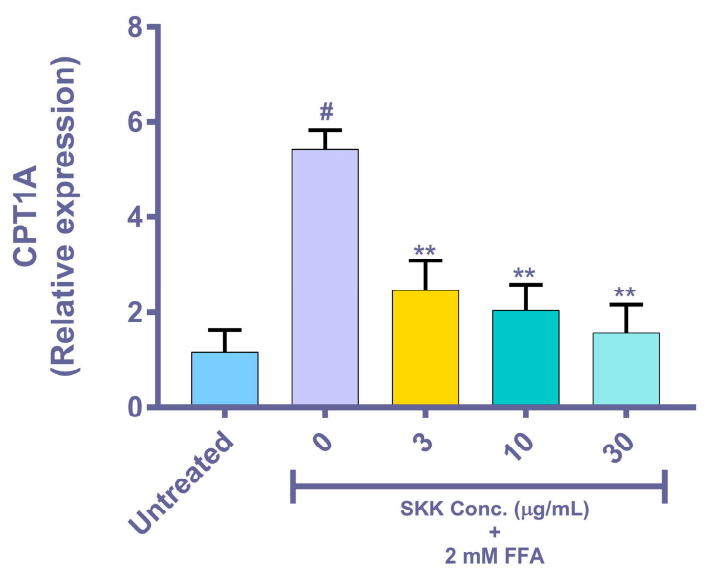

E

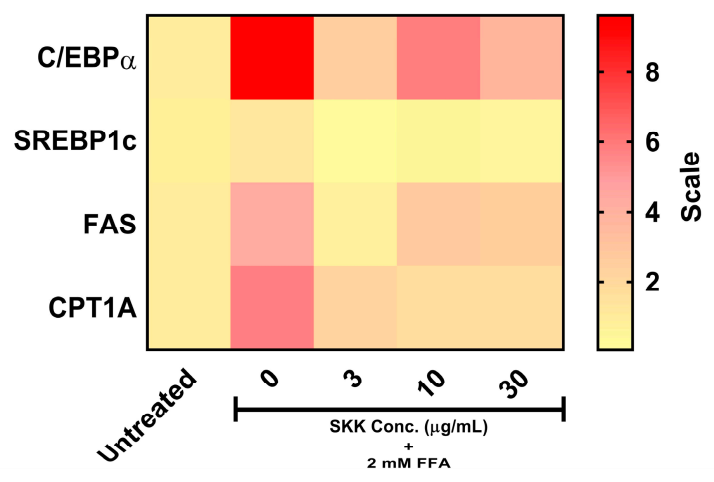

Figure 5. Gene expression analysis in HepG2 cells treated with free fatty acids and SKK. FFA-stimulated overexpression of steatosis associated genes: (A) C/EBP $\alpha,(\mathbf{B})$ FAS, (C) SREBP1c, and (D) CPT1A were observed in HepG2 cells. Pretreatment with SKK ameliorated the overexpression of genes induced by FFA treatment. (E) Heat-map presents a visual perspective of the up- and down-regulated genes in the $2 \mathrm{mM}$ FFA and SKK treated HepG2 cells. Results are displayed as mean \pm SEM. All the experiments were performed thrice in duplicate. For statistical analysis, one-way ANOVA with Dunnett's multiple comparisons was performed, where untreated control vs. $0 \mu \mathrm{g} / \mathrm{mL}=\# p$ value $<0.01$ and SKK test concentrations vs. $0 \mu \mathrm{g} / \mathrm{mL}={ }^{*} p$ value $<0.05,{ }^{* *} p$ value $<0.01$ and ${ }^{* * *} p$ value $<0.001$. 


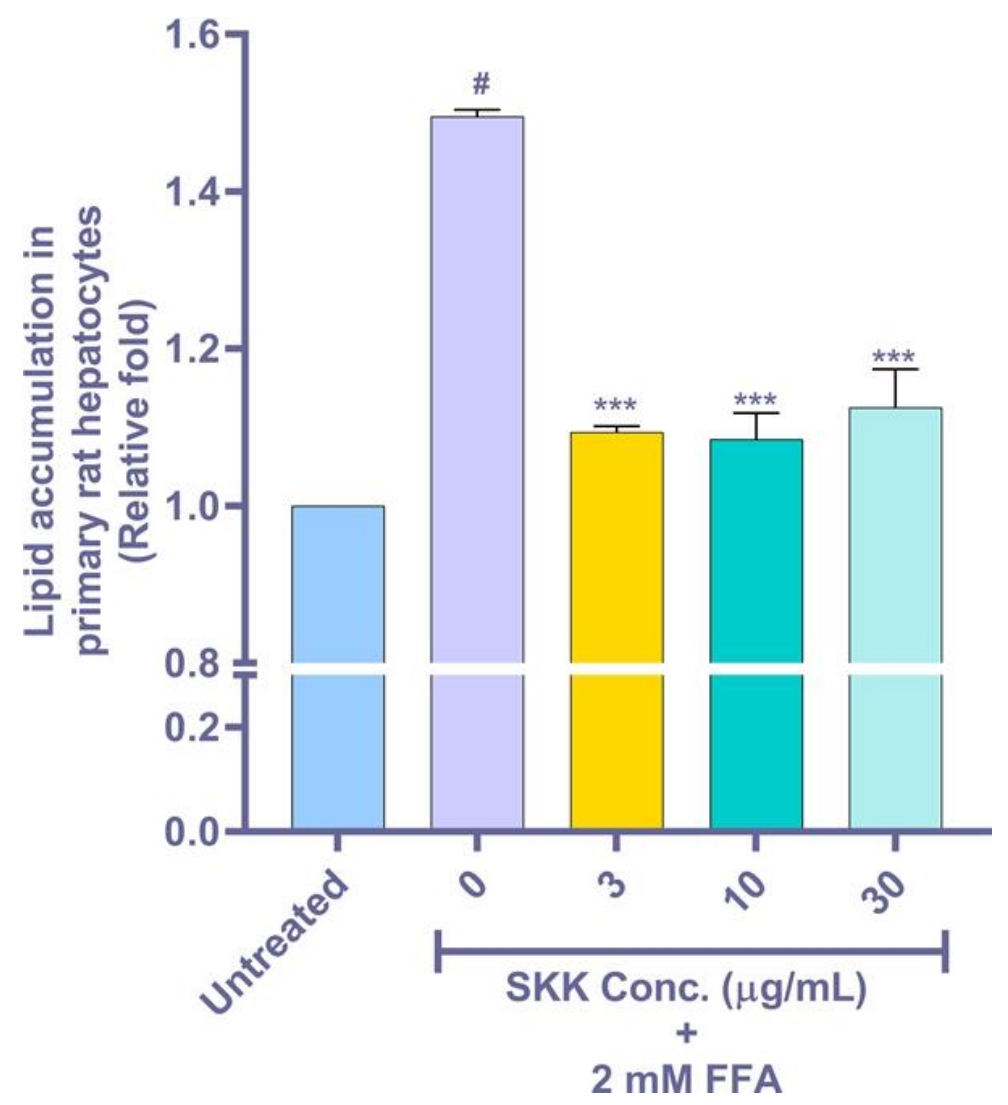

Figure 6. Lipid accumulation and its amelioration by SKK in primary rat hepatocytes. Steatosis induction was evaluated using isolated rat hepatocytes after induction with $2 \mathrm{mM}$ FFA mixture and treatment with SKK $(0,3,10$ and $30 \mu \mathrm{g} / \mathrm{mL})$ for $12 \mathrm{~h}$. Results are displayed as mean \pm SEM. The experiment was performed thrice in duplicate. For statistical analysis, one-way ANOVA with Dunnett's multiple comparisons was performed, where untreated control vs. $0 \mu \mathrm{g} / \mathrm{mL}=\# p$ value $<0.001$ and SKK test concentrations vs. $0 \mu \mathrm{g} / \mathrm{mL}={ }^{* * *} p$ value $<0.001$.

Overall results showed a protective effect of SKK in the human HepG2 cells and rat primary hepatocytes exposed to FFA. SKK treatment rescued the hepatocytes from excess FFA stimulated intracellular storage of lipid and triglycerides. SKK also modulated the mRNA expression of genes involved in triglyceride synthesis and intracellular storage. Finally, SKK treatment normalized the intracellular lipid and triglyceride levels of the hepatocyte, without changing their basal levels.

\section{Discussion}

Non-alcoholic fatty acid-induced hepatic steatosis is responsible for the obesity epidemic plaguing the modern world. The persistence of steatosis can lead to health-associated complications that can affect the individual quality of life. The present approach for treating free fatty acid (FFA) induced steatosis is limited to the application of thiazolidinediones and fibrates, in combination with lifestyle modifications [31]. Recent studies have shown that polyherbal formulations have equivalent efficacy to their allopathic counterparts in healing diseases without causing any side effects [32-34]. Therefore, herbal formulations such as Divya Sarva-Kalp-Kwath (SKK) marketed under its brand name 'Livogrit' is considered as an alternative therapeutic intervention against steatosis.

Plant metabolites play a major role in the disease modulating the efficacy of the herbal formulations. In our previous study, showing the efficacy of SKK formulation in ameliorating carbon tetrachloride-induced liver damages, we had identified the presence of marker plant metabolites gallic acid, caffeic acid, quercetin, catechin, rutin, and corilagin originating from the plant components Boerhavia diffusa L., P. niruri sensu Hook. f., and Solanum nigrum L. [19]. Hence, in the present study, 
the same plant metabolic compounds were analyzed using the HPTLC as a quality check for SKK. HPTLC findings indicated that these markers were amply present in the SKK formulation. Initial cell viability screening of the SKK showed them to be cytosafe in the human HepG2 cells with an $\mathrm{IC}_{50}$ value of $2801 \mu \mathrm{g} / \mathrm{mL}$. SKK ameliorated the FFA-induced cell-death in the HepG2 cells. A similar protective response of SKK was earlier observed by us in HepG2 cells treated with carbon tetrachloride [19]. Plant metabolites comprising of rotenoids, catechin, gallic acid, quercetin, rutin, corilagin, and caffeic acid play a major role in the hepatoprotective role of SKK against a wide range of liver ailments [19,35-38].

High levels of fatty acids obtained from the diet or those produced after de novo lipogenesis increase the hepatic influx of fatty acids and stimulate ceramide synthesis. The de novo ceramide synthesis that occurs using serine and palmitoyl CoA in the endoplasmic reticulum is upregulated in the presence of an excess of saturated fatty acids. Thus, an increase in ceramide levels has been known to promote triglyceride synthesis, induce hepatic lipid accumulation, lipotoxicity, and provoke apoptosis $[39,40]$. Intracellular increase in the triglyceride and extracellular lipid levels decrease in the glycerol level are the hallmarks of steatosis ailment [41]. Studies on steatosis seldom emphasize the diet-related increase in hepatic lipids and remain largely focused on the transcriptional segment of fatty acid synthesis enzymes. In our present study, we selected and utilized $2 \mathrm{mM}$ concentration of FFA for induction of steatosis, as other extracellular FFA concentrations did not induce a sizable fat accumulation in the HepG2 cells, under present experimental conditions. The observations are in line with the previous works of Lechón et al. and Ricchi et al. [11,13]. Therefore, this in vitro model might closely resemble the liver ailment conditions observed clinically in patients.

In our study, SKK reversed the FFA-induced steatosis conditions by reducing the intracellular lipid accumulation in both the human HepG2 cells and rat primary hepatocytes through pre- and concurrent treatments, respectively. SKK treatment also decreased the hepatocyte injury biomarker (AST) levels stimulated by FFA-induced liver damage. Our earlier study and Olaleye et al. have also shown that SKK or its component (Boerhavia diffusa) decreases AST levels under in vivo conditions [19,42]. In parallel, SKK also increased the presence of extracellular free glycerol molecules. These observations suggest that SKK modulated the process of triglyceride synthesis [43]. Polyphenol extracts obtained from S. nigrum and P. niruri has shown a protective effect against high fat diet-induced NAFLD in mice $[21,22,28]$.

Hepatic lipid metabolism is a complex process involving molecular events involving the roles of transcription factors, lipogenic, and fatty acid transporter genes [44-47]. Their modulation can lead to the development of steatosis along with reduced mitochondrial energy metabolism. In our study, HepG2 cells exposed to FFA showed upregulation in the mRNA expression of SREBP1c, C/EBP $\alpha$, FAS, and CPT1A genes. Prophylactic treatment of HepG2 cells with SKK downregulated these overexpressed genes. This observed downregulation of SREBP1c and C/EBP $\alpha$ by SKK might be directly related to the regulation of the AMPK protein phosphorylation, protecting against the progression of steatosis [43,48-50]. Kaempferol, a plant metabolite belonging to $B$. diffusa has been found to modulate the AMPK/mTOR pathway, an upstream regulator of SREPB-1c cleavage and activation in RIN-5F cells and murine pancreatic islets cells [51]. C/EBP $\alpha$ is upregulated in the liver of obese and aged mice leading to steatosis [52,53]. C/EBP-knockout in mice on a high-carbohydrate diet and obesity were found to have reduced triglyceride levels and downregulated expression of lipogenic genes [54]. Hence, in our study downregulation of the SREPB-1c and C/EBP $\alpha$ by SKK indicated a transcriptional level regulation of the FAA-induced steatosis.

Down-stream progression of lipogenesis is regulated by FAS, a cytosolic enzyme responsible for the synthesis of long-chained saturated fatty acids from acetyl-CoA and malonyl-CoA in the presence of NADPH [55]. Our study showed that SKK downregulated FAS overexpression in the FFA-stimulated HepG2 cells, and could be correlated to the decrease in the intracellular triglyceride storage and extracellular free glycerol level increase. Thus, SKK was able to disrupt the FAS-regulated fatty acid and triglyceride synthesis process. CPT1A is a liver isoform that catalyzes the rate-limiting steps for the transportation and conversion of fatty acids for mitochondrial beta-oxidation. Overexpression of 
CPT1A in FFA-treated HepG2 cells can be inferred as an adaptive response to metabolize the increased levels of available intracellular FFA. An increase in fatty acids is responsible for induction of CPT1A levels in the liver [56,57]. In the present study, CPT1A expression increased in HepG2 cells stimulated with 2 mM FFA. SKK treatment brought down this upregulated CPT1A levels to the normal level. This apparent normalization of CPT1A levels post SKK treatment points towards a chain of events leading to the attainment of homeostasis by the cells [58,59]. Prolonged enhancement of CPT1A activity can lead to increased mitochondrial energy metabolism leading to heightened reactive oxygen species generation and causing cellular damage and apoptosis [60]. Whereas, a decrease in CPT1A expression can lead to reduced $\beta$-oxidation in liver and could contribute to fatty acid accumulation and inflammation in hepatocytes [61]. Thus, our study could show that the reduced levels of intracellular lipids in both the pretreated and concurrently treated HepG2 cells and primary rat hepatocytes with SKK were through the modulation of the FFA-stimulated steatosis related transcription factors (SREBP1c and $\mathrm{C} / \mathrm{EBP} \alpha$ ), and associated lipogenic gene (FAS), which in turn also normalized the fatty acid transporter (CPT1A) gene expression levels responsible for the transport of fatty acids for mitochondrial energy metabolism. Modifications in the extracellular presence of glycerol in the FFA-treated HepG2 cells pretreated with SKK further strengthen this finding. Interestingly, the regulation of intracellular lipid and triglyceride levels by SKK was close to the basal level of HepG2 cells indicating that the treatment did not impede the normal cellular metabolic activities. Quercetin is a known suppressor of SREBP1c and FAS genes involved in lipogenesis [36]. Similarly, rutin has shown therapeutic efficacy in lowering triglyceride levels and lipid droplet accumulation in preclinical models [37]. Caffeic acid is a known enhancer of lipolysis via activation of adipose triglyceride lipase activity [35]. Other flavonoids detected in SKK are known to ameliorate FFA-induced steatosis by targeting multitude of pathways involved in the development and progression of steatosis and also act additionally as antioxidant and anti-inflammatory agents [38]. We did not investigate the role of SKK alone (without FFA) in stimulating steatosis associated genes since SKK appeared benign in terms of inducing any loss of cell viability or intracellular accumulation of lipids in the HepG2 cells.

This present study model has some limitations in terms of organ-based tissue complexity and relative mode of actions. While in-vitro and ex-vivo models are good for exploring the molecular mechanisms, their results often depict signs of singularity in response. One example can be a study performed by Parra-Vargas et al. wherein they found that their test compound delphinidin used for reducing steatosis showed efficacy in vitro but not in their high-fat diet mouse model [59]. Another likely limitation is the lack of immune profiling, which is involved in the progression to fibrosis. Further, exploratory animal and human trials involving SKK will provide additional support to our observations.

In conclusion, the study outcome showed that treatment of the FFA exposed HepG2 cells and primary rat hepatocytes with tri-herbal formulation SKK (branded as Livogrit), protected against the onset and progression of hepatic lipid accumulation and steatosis. This hepatoprotective effects of SKK were facilitated through the regulation of key steatosis associated genetic elements such as transcription factors and fatty acid metabolizing/transporting genes. Furthermore, our work showed that SKK was cytosafe to hepatocytes and supported the recovery of hepatocyte viability. These results suggest that SKK may be an effective therapeutic option for treating hepatic steatosis. Further investigations would help in understanding the specific roles of plant metabolites present in SKK, in ameliorating the molecular pathology of steatosis.

\section{Materials and Methods}

\subsection{Chemicals and Reagents}

SKK was obtained from Divya Pharmacy, Haridwar, India, under its name 'Divya Sarva-Kalp-Kwath' (Batch no \#A-SKK056). For the preparation of SKK extract (which has been branded as tablet Livogrit, by the manufacturer), we utilized the method previously described [19]. 
Briefly, $7.5 \mathrm{~g}$ of SKK powder was weighed and mixed with $400 \mathrm{~mL}$ of water. The mixture was boiled until a volume of $100 \mathrm{~mL}$ remained. The resultant decoction was dried using lyophilizer, and $853 \mathrm{mg}$ of powder was obtained. Triglyceride analysis reagents were procured from Randox Laboratories Ltd., Crumlin, United Kingdom. The standards used for HPTLC were gallic acid (Sigma-Aldrich, St. Louis, MO, USA), caffeic acid (Sigma-Aldrich), quercetin (SRL, New Delhi, India), catechin (Sigma-Aldrich), rutin (Sigma-Aldrich), and corilagin (Natural remedies, Chandigarh, India). All other chemicals and reagents used for the tissue processing work were of the highest analytical grade.

\subsection{Metabolite Analysis of SKK}

Of the dried extract a $500 \mathrm{mg}$ sample was dissolved in $10 \mathrm{~mL}$ of water followed by $20 \mathrm{~min}$ of sonication (normal phase, GT sonic, Guangdong, China) and centrifugation at $3000 \mathrm{rpm}$ in Sorvall ST8R benchtop centrifuge (Thermo Ficher Scientific, Waltham, MA, USA) for $15 \mathrm{~min}$. From the supernatant, $10 \mu \mathrm{L}$ aliquot and $8 \mu \mathrm{L}$ of a standard solution were loaded as $8 \mathrm{~mm}$ band length in a 60 F254 $(10 \mathrm{~cm} \times 10 \mathrm{~cm}$, DA Kieselgel 60 F254, CCM Gel de silica 60 F254) plate (Merck, Kenilworth, NJ, USA) using a Hamilton syringe and ATS4 instrument (CAMAG, Muttenz, Switzerland). The samples-loaded plate was kept in TLC twin trough developing chamber (after saturation with solvent vapor) with mobile phase for chromatograph 1 (chloroform: ethyl acetate: acetone: formic acid (8: 6: 4:2)) and chromatograph 2 (ethyl acetate: acetic acid: formic acid water (10: 1: 1: 2.3)). Development of the plate was done in the respective mobile phase up to $80 \mathrm{~mm}$ after which the plate was air-dried to remove the solvents. The plate was kept in a photo-documentation chamber (CAMAG visualizer) and the images were documented at UV $254 \mathrm{~nm}$ mode using the photo-documentation chamber. The plate was fixed and scanning was done at $280 \mathrm{~nm}$ by the TLC scanner. Total phenolic content of SKK was also analyzed via the Folin-Ciocalteu method using gallic acid as a standard [62].

\subsection{In-Vitro Cell Culture}

HepG2 cells were obtained from the National Centre for Cell Science, Pune, India (local repository for the American Type Cell Culture (ATCC)), proliferated within two passage numbers, and stored in liquid nitrogen at passage number 17. Cells were cultured in high glucose ( $4.5 \mathrm{gm} / \mathrm{L})$ DMEM cell culture media (Gibco, Evansville, IN, USA) supplemented with 10\% FBS (HiMedia, Mumbai, India) and $100 \mathrm{U} / \mathrm{mL}$ penicillin/streptomycin (Thermo Fisher Scientific, Waltham, MA, USA) and maintained at $37{ }^{\circ} \mathrm{C}$ and $5 \% \mathrm{CO}_{2}$ [63]. Cells were passaged at $70 \%$ confluence and used for assays based on the number of cells required in each experiment. All experiments were conducted within 5 passages.

\subsection{Cell Viability Analysis}

HepG2 were plated at a density of $1 \times 10^{4}$ cells/ well in 96 well-plate and preincubated. The cells were treated with SKK extract $(0,0.1,0.3,1,3,10,30,100,300$, and $1000 \mu \mathrm{g} / \mathrm{mL})$ prepared in DMEM media containing 1\% BSA (HiMedia, Mumbai, India) and incubated for $48 \mathrm{~h}$. For the efficacy study, HepG2 cells were pretreated with SKK $(0,3,10$, and $30 \mu \mathrm{g} / \mathrm{mL})$ for $24 \mathrm{~h}$, followed by a combined SKK $(0,3,10$, and $30 \mu \mathrm{g} / \mathrm{mL}$ ) and $2 \mathrm{mM}$ FFA (oleic acid $1.34 \mathrm{mM}$ and palmitic acid $0.66 \mathrm{mM}$ ) preconjugated with BSA for $48 \mathrm{~h}$. Cell viability was determined using Alamar blue ${ }^{\circledR}$ dye and fluorescence was measured at an excitation wavelength of $560 \mathrm{~nm}$ and emission wavelength $590 \mathrm{~nm}$ using EnVision multimode plate reader (PerkinElmer, Waltham, MA, USA).

\subsection{Oil Red 'O' (ORO) Staining Based Lipid Accumulation Analysis}

Intracellular lipids accumulation analysis was performed in HepG2 cells pretreated with SKK $(0,3,10$, and $30 \mu \mathrm{g} / \mathrm{mL})$ for $24 \mathrm{~h}$, followed by, a combined SKK $(0,3,10$, and $30 \mu \mathrm{g} / \mathrm{mL})$ and $2 \mathrm{mM}$ FFA (oleic acid $1.32 \mathrm{mM}$ and palmitic acid $0.66 \mathrm{mM}$ ) pre-conjugated with BSA for $48 \mathrm{~h}$. The treated cells were washed with PBS and fixed in 10\% formalin for $30 \mathrm{~min}$. A $0.6 \%(w / v)$ stock solution of ORO was prepared in 2-propanol (IPA) and filtered through a $0.22 \mu \mathrm{m}$ membrane filter. A working solution of ORO was prepared by mixing 3 parts of the stock solution and 2 parts of $\mathrm{ddH}_{2} \mathrm{O}$. The fixed HepG2 
cells were stained with the ORO working solution for $40 \mathrm{~min}$ at room temperature. The stained HepG2 cells were washed four times with ddH2O to remove unbound stain and qualitatively analyzed using a Zeiss Primovert inverted bright-field microscope. For lipid quantification, 100\% of IPA was added to ORO stained HepG2 cells and the dissolved cellular stain was measured at an absorbance wavelength of $518 \mathrm{~nm}$ using an EnVision multimode plate reader (PerkinElmer, Waltham, MA, USA).

\subsection{Intracellular Triglyceride Estimation}

HepG2 cells were plated at a density of $1 \times 10^{5}$ cells/well in a 12 -well plate and preincubated overnight. The cells were pretreated with a varying dose of SKK $(0,3,10$, and $30 \mu \mathrm{g} / \mathrm{mL})$, followed by a combination of $2 \mathrm{mM}$ FFA and $\operatorname{SKK}(0,3,10$, and $30 \mu \mathrm{g} / \mathrm{mL})$ for a period of $48 \mathrm{~h}$. On the completion of the exposure period, exposed cell culture media was collected for extracellular glycerol analysis, and cells were washed thrice with PBS and treated with ice-cold $\left(4^{\circ} \mathrm{C}\right) \mathrm{PBS}$. The cells were scraped using a cell-scraper and lysed after two freeze-thaw cycles in liquid nitrogen. Triglyceride analysis in the cell lysate was done using the Randox triglyceride assay kit and Randox Monaco clinical chemistry analyzer (Randox Laboratories Ltd., Crumlin, UK). The analysis was performed following the manufacturer's guidelines. Total protein content of the individual samples was measured using the bicinchoninic acid (BCA) colorimetric kit (Thermo Fisher Scientific, Waltham, MA, USA) and the measurement was obtained at $562 \mathrm{~nm}$ using EnVision plate reader (PerkinElmer, Waltham, MA, USA). Measured levels of proteins per sample were used for normalization of the triglyceride levels.

\subsection{AST Estimation}

Cells were plated at a density of $1 \times 10^{5}$ cells/ well in a 12 -well plate and incubated overnight. The cells were pretreated with a varying dose of SKK $(0-30 \mu \mathrm{g} / \mathrm{mL})$, followed by a combination of $2 \mathrm{mM}$ FFA and SKK $(0-30 \mu \mathrm{g} / \mathrm{mL})$ for a period of $48 \mathrm{~h}$ post which the supernatant was collected and centrifuged at $100 \times g$ for $5 \mathrm{~min}$ to remove cell debris. The supernatant was then transferred to $1.5 \mathrm{~mL}$ vials of Biochemical analyzer XL 640 (Erba Mannheim, Czech Republic). The analysis was performed following the manufacturer's guidelines. Total protein content of the sample was analyzed using the BCA kit (mentioned above) and data were normalized using obtained values.

\subsection{Estimation of Extracellular Free Glycerol}

The cell culture media collected from the triglyceride assay (see above) was centrifuged at $100 \times g$ for $5 \mathrm{~min}$ for removing the cell debris. The supernatant was collected and transferred to $2 \mathrm{~mL}$ vial for gas chromatography-mass spectroscopy (GC-MS). The analysis was performed on GC-MS (7000D GC/MS triple quad attached with the 7890B GC system (Agilent Technologies, Santa Clara, CA, USA) instrument. Data acquisition and analysis was performed using mass hunter software. For separation, the DB-624 capillary column $(30 \mathrm{~m} \times 0.25 \mathrm{~mm}, 0.25 \mu \mathrm{m})$ was utilized and helium was used as carrier gas with a flow-rate of $1.5 \mathrm{~mL} / \mathrm{min}$. The temperature of the injector was set at $280^{\circ} \mathrm{C}$ and the split ratio was adjusted to 5:1. The column temperature was set at $80^{\circ} \mathrm{C}$ (with $2 \mathrm{~min}$ hold) and programmed at $5^{\circ} \mathrm{C} / \mathrm{min}$ to $150{ }^{\circ} \mathrm{C}$ (with $2 \mathrm{~min}$ hold), followed by $10^{\circ} \mathrm{C} / \mathrm{min}$ to $200^{\circ} \mathrm{C}$ (with $2 \mathrm{~min}$ hold). The temperature of the GC-MS ion source was $240^{\circ} \mathrm{C}$ and its ionization potential was $70 \mathrm{eV}$. The spectra were acquired using the MS1 SIM mode with selected ion for glycerol (Quantifier-61 and Qualifier-43). A standard curve was prepared using glycerol concentrations of 10, 20, 50, 100, and $200 \mathrm{ppm}$. The area under the curve was analyzed for each spectrum of glycerol for quantification purposes. Total protein content of the sample was analyzed using BCA kit (mentioned above), which was used for the normalization of glycerol levels per sample.

\subsection{Real-Time PCR (RT-PCR) Based Gene Expression Quantification}

Total RNA was isolated from HepG2 after treatment using the RNeasy mini kit (Qiagen, Hilden, Germany) following the manufacturer's protocol. The cDNA synthesis was done using the Verso cDNA synthesis kit (Thermo Fisher Scientific, Waltham, MA, USA). cDNA samples were mixed 
with the PowerUp SYBR Green Master Mix (Applied Biosystems, Foster city, CA, USA) and RT-PCR was performed using qTOWER ${ }^{3} \mathrm{G}$ (Analytik-Jena, Jena, Germany). The RT-PCR cycling parameters included an initial denaturation of $95^{\circ} \mathrm{C}$ for $10 \mathrm{~min}$ and a primer extension at $95^{\circ} \mathrm{C}$ for $15 \mathrm{~s}$ and $60{ }^{\circ} \mathrm{C}$ for one minute with 40 cycles. Ct values were obtained, and relative expression $2^{(-\Delta \Delta \mathrm{Ct})}$ was calculated and analyzed for changes in mRNA expression. Primers used for the study are mentioned in Table 1. Peptidylprolyl Isomerase A (PPIA) gene was used as a housekeeping gene.

Table 1. Primers used for the analysis of gene expression.

\begin{tabular}{ll}
\hline Gene Name & Primer Sequence \\
\hline \multirow{2}{*}{ C/EBP $\alpha$} & F: 5' 5GGACAAGAACAGCAACGAGTA-3' $^{\prime}$ \\
& R: 5'-ATTGTCACTGGTCAGCTCCAG-3' \\
SREBP1c & F: 5'-GCGCCTTGACAGGTGAAGTC-3' \\
& R: 5'-GCCAGGGAAGTCACTGTCTTG-3' \\
FAS & F: 5'-CCCCTGATGAAGAAGGATCA-3' \\
& R: 5'-ACTCCACAGGTGGGAACAAG-3' \\
CPT1A & F: 5'-CCTCCGTAGCTGACTCGGTA-3' \\
& R: 5'-GGAGTGACCGTGAACTGAAA-3' \\
PPIA & F: 5'-CCCACCGTGTTCTTCGACATT-3' \\
& R: 5'-GGACCCGTATGCTTTAGGATGA-3' \\
\hline
\end{tabular}

\subsection{Primary Rat Hepatocyte Isolation and Treatment}

Male Wistar rats (250-300 gm) were procured from Hylasco Bio-Technology Pvt. Ltd. (Hyderabad, India). All the animals were placed under a controlled environment with a relative humidity of 60-70\% and 12:12 $\mathrm{h}$ light and dark cycle in a registered animal house (1964/PO/RC/S/17/CPCSEA) of Patanjali Research Institute, Haridwar, India. The animals were fed a standard pellet diet (Purina Lab Diet, St. Louis, MO, USA) and sterile filtered water ad libitum. The animals used for this study were part of protocol approved by the Institutional Animal Ethical Committee (IAEC) of Patanjali Research Institute vide IAEC approval number: LAF/PCY/2020-39.

Isolation of primary hepatocytes was isolated from the liver tissues of three Wistar rats separately following the protocol mentioned by Shen et al., 2012 with slight modification [64]. Briefly, liver was cut into $1 \mathrm{~mm}$ thick pieces and perfused with hepatocyte wash medium (Gibco, Evansville, IN, USA). These liver pieces were placed in $0.25 \%$ Trypsin + EDTA solution (Invitrogen, Carlsbad CA, USA) for $30 \mathrm{~min}$ till transformation into soft mushy texture. The whole tissue was then forced to pass through 100-40-micron sieves, serially. The filtrate was added to $30 \mathrm{~mL}$ of complete DMEM medium and centrifuged at $50 \times g$. The pellet was collected and cell viability of the isolated hepatocytes was measured up to $65 \%$ using trypan blue-based assay. Cells were plated in 96 well plates at a cell density of $2 \times 10^{4}$ cells/well and maintained in normal Williams' media E (Gibco, Evansville, IN, USA) and Opti MEM (Gibco, Evansville, IN, USA) mixed in 1:1 ratio supplemented with 5\% FBS and $2 \%$ antibiotic at $37{ }^{\circ} \mathrm{C}$ and $5 \% \mathrm{CO}_{2}$. For functional assay, cells were plated in a 12 -well plate at a density of $3 \times 10^{5}$ cells/well. Albumin was analyzed post $24 \mathrm{~h}$ of culture from the supernatant of plated cells using commercially available kits for Albumin (Randox Laboratories Ltd., Crumlin, UK) and measured using Randox Monaco clinical chemistry analyzer (Randox Laboratories Ltd., Crumlin, UK), following the manufacturer's instructions. The primary hepatocytes were treated with a combination of $2 \mathrm{mM}$ FFA along with varying concentrations of $\operatorname{SKK}(0,3,10$, and $30 \mu \mathrm{g} / \mathrm{mL})$ and incubated for $12 \mathrm{~h}$, following which the intracellular lipid accumulation was evaluated using the ORO assay.

\subsection{Statistical Analysis}

All the experiments were repeated thrice in triplicate. Data represents mean \pm standard error of mean (SEM) over 95\% confidence intervals. Statistical analysis was performed using one-way ANOVA with Dunnett's multiple comparisons post-hoc test. Statistical analysis was performed using GraphPad 
Prism 7 (GraphPad Software, Inc., San Diego, CA, USA). The results were considered to be statistically significant at a probability level of $p$ value $<0.05$.

Author Contributions: A.B. provided broad direction for the study, identified the test formulation, generated resources, and gave approval for the manuscript. V.G. performed the in vitro and ex vivo experiments, analyzed data and wrote the manuscript. R.S. performed mRNA isolation, cDNA synthesis, and RT-PCR analysis. Y.V. performed the GC-MS analysis. M.J. performed HPTLC and total phenolic content analysis and J.S. performed data analysis. K.B. designed and supervised the study, performed data curing, and revised the manuscript. A.V. supervised overall research project planning, generated resources, reviewed, and approved the manuscript. All authors have read and agreed to the published version of the manuscript.

Funding: This research work was funded internally by Patanjali Research Foundation Trust, Haridwar, India.

Acknowledgments: We are grateful to Mr. Sandeep Sinha for his support with ex- vivo sample collections. We extend our gratitude to Mr. Sudeep Verma for his analytical support with GC-MS analysis and to Mr. Dinesh Pali and Dr. Shobhit Chandra for their support with AST analysis. We also appreciate the timely support provided by Ms. Deepika Mehra for the analysis of TG and albumin. We gratefully acknowledge Mr. Tarun Rajput, Mr. Gagan Kumar, and Mr. Lalit Mohan for their swift administrative supports.

Conflicts of Interest: Patanjali Research Institute (PRI) is an autonomous, non-profit organization, governed by Patanjali Research Foundation Trust, Haridwar, India. The authors declare that this research was conducted in the absence of any other commercial or financial relationships that could be construed as a potential conflict of interest.

\section{References}

1. Nassir, F.; Rector, R.S.; Hammoud, G.M.; Ibdah, J.A. Pathogenesis and Prevention of Hepatic Steatosis. Gastroenterol. Hepatol. 2015, 11, 167-175.

2. Asrani, S.K.; Devarbhavi, H.; Eaton, J.; Kamath, P.S. Burden of Liver Diseases in the World. J. Hepatol. 2019, 70, 151-171. [CrossRef] [PubMed]

3. Mokdad, A.H.; Forouzanfar, M.H.; Daoud, F.; Mokdad, A.; El Bcheraoui, C.; Moradi-Lakeh, M.; Kyu, H.H.; Barber, R.M.; Wagner, J.; Cercy, K.; et al. Global Burden of Diseases, Injuries, and Risk Factors for Young People's Health During 1990-2013: A Systematic Analysis for the Global Burden of Disease Study 2013. Lancet 2016, 387, 2383-2401. [CrossRef]

4. Pagadala, M.; Kasumov, T.; McCullough, A.J.; Zein, N.N.; Kirwan, J.P. Role of Ceramides in Nonalcoholic Fatty Liver Disease. Trends Endocrinol. Metab. 2012, 23, 365-371. [CrossRef] [PubMed]

5. Perumpail, B.J.; Khan, M.A.; Yoo, E.R.; Cholankeril, G.; Kim, D.; Ahmed, A. Clinical Epidemiology and Disease Burden of Nonalcoholic Fatty Liver Disease. World J. Gastroenterol. 2017, 23, 8263-8276. [CrossRef]

6. Araya, J.; Rodrigo, R.; Videla, L.A.; Thielemann, L.; Orellana, M.; Pettinelli, P.; Poniachik, J. Increase in Long-Chain Polyunsaturated Fatty Acid n-6/N-3 Ratio in Relation to Hepatic Steatosis in Patients with Non-Alcoholic Fatty Liver Disease. Clin. Sci. 2004, 106, 635-643. [CrossRef]

7. Joshi-Barve, S.; Barve, S.S.; Amancherla, K.; Gobejishvili, L.; Hill, D.; Cave, M.; Hote, P.; McClain, C.J. Palmitic Acid Induces Production of Proinflammatory Cytokine Interleukin-8 from Hepatocytes. Hepatology 2007, 46, 823-830. [CrossRef]

8. Tang, Y.; Bian, Z.; Zhao, L.; Liu, Y.; Liang, S.; Wang, Q.; Han, X.; Peng, Y.; Chen, X.; Shen, L.; et al. Interleukin-17 Exacerbates Hepatic Steatosis and Inflammation in Non-Alcoholic Fatty Liver Disease. Clin. Exp. Immunol. 2011, 166, 281-290. [CrossRef]

9. Niklas, J.; Bonin, A.; Mangin, S.; Bucher, J.; Kopacz, S.; Matz-Soja, M.; Thiel, C.; Gebhardt, R.; Hofmann, U.; Mauch, K. Central Energy Metabolism Remains Robust in Acute Steatotic Hepatocytes Challenged by a High Free Fatty Acid Load. BMB Rep. 2012, 45, 396-401. [CrossRef]

10. Pan, Z.; Wang, J.-W.; Tang, H.; Li, L.; Lv, J.; Xia, L.; Han, C.; Xu, F.; He, H.; Xu, H.; et al. Effects of Palmitic Acid on Lipid Metabolism Homeostasis and Apoptosis in Goose Primary Hepatocytes. Mol. Cell. Biochem. 2010, 350, 39-46. [CrossRef]

11. Gómez-Lechón, M.J.; Donato, M.T.; Martínez-Romero, A.; Jiménez, N.; Castell, J.V.; O’Connor, J.-E. A Human Hepatocellular in Vitro Model to Investigate Steatosis. Chem. Interactions 2007, 165, 106-116. [CrossRef]

12. Mantzaris, M.D.; Tsianos, E.V.; Galaris, D. Interruption of Triacylglycerol Synthesis in the Endoplasmic Reticulum Is the Initiating Event for Saturated Fatty Acid-Induced Lipotoxicity in Liver Cells. FEBS J. 2010, 278, 519-530. [CrossRef] [PubMed] 
13. Ricchi, M.; Odoardi, M.R.; Carulli, L.; Anzivino, C.; Ballestri, S.; Pinetti, A.; Fantoni, L.I.; Marra, F.; Bertolotti, M.; Banni, S.; et al. Differential Effect of Oleic and Palmitic Acid on Lipid Accumulation and Apoptosis in Cultured Hepatocytes. J. Gastroenterol. Hepatol. 2009, 24, 830-840. [CrossRef] [PubMed]

14. Swagell, C.D.; Henly, D.C.; Morris, C.P. Expression Analysis of a Human Hepatic Cell Line in Response to Palmitate. Biochem. Biophys. Res. Commun. 2005, 328, 432-441. [CrossRef] [PubMed]

15. Park, M.; Yoo, J.-H.; Lee, Y.-S.; Lee, H.-J. Lonicera Caerulea Extract Attenuates Non-Alcoholic Fatty Liver Disease in Free Fatty Acid-Induced HepG2 Hepatocytes and in High Fat Diet-Fed Mice. Nutrients 2019, 11, 494. [CrossRef] [PubMed]

16. Weber, M.; Mera, P.; Casas, J.; Salvador, J.; Rodríguez, A.; Alonso, S.; Sebastián, D.; Soler-Vázquez, M.C.; Montironi, C.; Recalde, S.; et al. Liver CPT1A Gene Therapy Reduces diet-induced Hepatic Steatosis in Mice and Highlights Potential Lipid Biomarkers for Human NAFLD. FASEB J. 2020, 34, 11816-11837. [CrossRef] [PubMed]

17. Donnelly, K.L.; Smith, C.I.; Schwarzenberg, S.J.; Jessurun, J.; Boldt, M.D.; Parks, E.J. Sources of Fatty Acids Stored in Liver and Secreted via Lipoproteins in Patients with Nonalcoholic Fatty Liver Disease. J. Clin. Investig. 2005, 115, 1343-1351. [CrossRef]

18. Jian, T.; Lü, H.; Ding, X.; Wu, Y.; Zuo, Y.; Li, J.; Chen, J.; Gu, H. Polyphenol-Rich Trapa Quadrispinosa Pericarp Extract Ameliorates High-Fat Diet Induced Non-Alcoholic Fatty Liver Disease by Regulating Lipid Metabolism and Insulin Resistance in Mice. PeerJ 2019, 7, e8165. [CrossRef]

19. Balkrishna, A.; Sakat, S.S.; Ranjan, R.; Joshi, K.; Shukla, S.; Joshi, K.; Verma, S.; Gupta, A.; Bhattacharya, K.; Varshney, A. Polyherbal Medicine Divya Sarva-Kalp-Kwath Ameliorates Persistent Carbon Tetrachloride Induced Biochemical and Pathological Liver Impairments in Wistar Rats and in HepG2 Cells. Front. Pharmacol. 2020, 11, 288. [CrossRef]

20. Thomford, N.E.; Awortwe, C.; Dzobo, K.; Adu, F.; Chopera, D.; Wonkam, A.; Skelton, M.; Blackhurst, D.; Dandara, C. Inhibition of CYP2B6 by Medicinal Plant Extracts: Implication for Use of Efavirenz and Nevirapine-Based Highly Active Anti-Retroviral Therapy (HAART) in Resource-Limited Settings. Molecules 2016, 21, 211. [CrossRef]

21. Huang, C.-Z.; Tung, Y.-T.; Hsia, S.-M.; Wu, C.-H.; Yen, G.-C. The Hepatoprotective Effect of Phyllanthus Emblica, L. Fruit on High Fat Diet-Induced Non-Alcoholic Fatty Liver Disease (NAFLD) in SD Rats. Food Funct. 2017, 8, 842-850. [CrossRef] [PubMed]

22. Tung, Y.-T.; Huang, C.-Z.; Lin, J.-H.; Yen, G.-C. Effect of Phyllanthus Emblica, L. Fruit on Methionine and Choline-Deficiency Diet-Induced Nonalcoholic Steatohepatitis. J. Food Drug Anal. 2018, 26, 1245-1252. [CrossRef] [PubMed]

23. Bhattacharjee, R.; Sil, P.C. Protein Isolate from the HerbPhyllanthus NiruriModulates Carbon Tetrachloride-Induced Cytotoxicity in Hepatocytes. Toxicol. Mech. Methods 2007, 17, 41-47. [CrossRef] [PubMed]

24. Harish, R.; Shivanandappa, T. Antioxidant Activity and Hepatoprotective Potential of Phyllanthus Niruri. Food Chem. 2006, 95, 180-185. [CrossRef]

25. Jantan, I.; Haque, A.; Ilangkovan, M.; Arshad, L. An Insight Into the Modulatory Effects and Mechanisms of Action of Phyllanthus Species and Their Bioactive Metabolites on the Immune System. Front. Pharmacol. 2019, 10, 878. [CrossRef]

26. Kaur, N.; Kaur, B.; Sirhindi, G. Phytochemistry and Pharmacology OfPhyllanthus niruriL: A Review. Phytotherapy Res. 2017, 31, 980-1004. [CrossRef]

27. Kirtikar, K.R.; Basu, B.D. Indian Medicinal Plants, 2nd ed.; Lalit Mohan Basu Publication: Allahabad, India, 1956; p. 852.

28. Chang, J.-J.; Chung, D.-J.; Lee, Y.-J.; Wen, B.-H.; Jao, H.-Y.; Wang, C.-J. Solanum NigrumPolyphenol Extracts Inhibit Hepatic Inflammation, Oxidative Stress, and Lipogenesis in High-Fat-Diet-Treated Mice. J. Agric. Food Chem. 2017, 65, 9255-9265. [CrossRef]

29. Available online: https://www.ncbi.nlm.nih.gov/books/NBK482489/ (accessed on 10 September 2020).

30. Fuchs, M. Non-Alcoholic Fatty Liver Disease: The Bile Acid-Activated Farnesoid X Receptor as an Emerging Treatment Target. J. Lipids 2011, 2012, 934396. [CrossRef]

31. Jadeja, R.N.; Devkar, R.V.; Nammi, S. Herbal Medicines for the Treatment of Nonalcoholic Steatohepatitis: Current Scenario and Future Prospects. Evidence-Based Complement. Altern. Med. 2014, 2014, 648308. [CrossRef] 
32. Balkrishna, A.; Ranjan, R.; Sakat, S.S.; Sharma, V.K.; Shukla, R.; Joshi, K.; Devkar, R.; Sharma, N.; Saklani, S.; Pathak, P.; et al. Evaluation of Polyherbal Ayurvedic Formulation 'Peedantak Vati' for Anti-Inflammatory and Analgesic Properties. J. Ethnopharmacol. 2019, 235, 361-374. [CrossRef]

33. Balkrishna, A.; Sakat, S.S.; Joshi, K.; Joshi, K.; Sharma, V.; Ranjan, R.; Bhattacharya, K.; Varshney, A. Cytokines Driven Anti-Inflammatory and Anti-Psoriasis Like Efficacies of Nutraceutical Sea Buckthorn (Hippophae Rhamnoides) Oil. Front. Pharmacol. 2019, 10, 10. [CrossRef] [PubMed]

34. Balkrishna, A.; Sakat, S.S.; Joshi, K.; Paudel, S.; Joshi, D.; Joshi, K.; Ranjan, R.; Gupta, A.; Bhattacharya, K.; Varshney, A. Herbo-Mineral Formulation 'Ashwashila' Attenuates Rheumatoid Arthritis Symptoms in Collagen-Antibody-Induced Arthritis (CAIA) Mice Model. Sci. Rep. 2019, 9, 8025. [CrossRef]

35. Huang, W.-C.; Chen, Y.-L.; Liu, H.-C.; Wu, S.-J.; Liou, C.-J. Ginkgolide C Reduced Oleic Acid-Induced Lipid Accumulation in HepG2 Cells. Saudi Pharm. J. 2018, 26, 1178-1184. [CrossRef]

36. Li, X.; Wang, R.; Zhou, N.; Wang, X.; Liu, Q.; Bai, Y.; Bai, Y.; Liu, Z.; Yang, H.; Zou, J.; et al. Quercetin Improves Insulin Resistance and Hepatic Lipid Accumulation in Vitro in a NAFLD Cell Model. Biomed. Rep. 2012, 1, 71-76. [CrossRef]

37. Liu, Q.; Pan, R.; Ding, L.; Zhang, F.; Hu, L.; Ding, B.; Zhu, L.; Xia, Y.; Dou, X. Rutin Exhibits Hepatoprotective Effects in a Mouse Model of Non-Alcoholic Fatty Liver Disease by Reducing Hepatic Lipid Levels and Mitigating Lipid-Induced Oxidative Injuries. Int. Immunopharmacol. 2017, 49, 132-141. [CrossRef]

38. Van De Wier, B.; Koek, G.H.; Bast, A.; Haenen, G.R.M.M. The Potential of Flavonoids in the Treatment of Non-Alcoholic Fatty Liver Disease. Crit. Rev. Food Sci. Nutr. 2015, 57, 834-855. [CrossRef]

39. Yang, R.-X.; Pan, Q.; Liu, X.-L.; Zhou, D.; Xin, F.-Z.; Zhao, Z.-H.; Zhang, R.-N.; Zeng, J.; Qiao, L.; Hu, C.-X.; et al. Therapeutic Effect and Autophagy Regulation of Myriocin in Nonalcoholic Steatohepatitis. Lipids Heal. Dis. 2019, 18, 1-11. [CrossRef] [PubMed]

40. Simon, J.; Ouro, A.; Ala-Ibanibo, L.; Presa, N.; Delgado, T.C.; Martínez-Chantar, M.L. Sphingolipids in Non-Alcoholic Fatty Liver Disease and Hepatocellular Carcinoma: Ceramide Turnover. Int. J. Mol. Sci. 2019, 21, 40. [CrossRef] [PubMed]

41. Zhao, N.-Q.; Li, X.-Y.; Wang, L.; Feng, Z.-L.; Li, X.-F.; Wen, Y.-F.; Han, J.-X. Palmitate Induces Fat Accumulation by Activating C/EBP $\beta$-Mediated G0S2 Expression in HepG2 Cells. World J. Gastroenterol. 2017, 23, 7705-7715. [CrossRef] [PubMed]

42. Mishra, S.; Aeri, V.; Gaur, P.K.; Jachak, S.M. Phytochemical, Therapeutic, and Ethnopharmacological Overview for a Traditionally Important Herb:Boerhavia DiffusaLinn. BioMed Res. Int. 2014, 2014, 808302. [CrossRef]

43. Xu, Y.; Guo, W.; Zhang, C.; Chen, F.; Tan, H.Y.; Li, S.; Wang, N.; Feng, Y.-B. Herbal Medicine in the Treatment of Non-Alcoholic Fatty Liver Diseases-Efficacy, Action Mechanism, and Clinical Application. Front. Pharmacol. 2020, 11, 601. [CrossRef]

44. Han, Y.; Hu, Z.; Cui, A.; Liu, Z.; Ma, F.; Xue, Y.; Liu, Y.; Zhang, F.; Zhao, Z.; Yu, Y.; et al. Post-Translational Regulation of Lipogenesis via AMPK-Dependent Phosphorylation of Insulin-Induced Gene. Nat. Commun. 2019, 10, 1-13. [CrossRef]

45. Liou, C.-J.; Wei, C.-H.; Chen, Y.-L.; Cheng, C.-Y.; Wang, C.-L.; Huang, W.-C. Fisetin Protects Against Hepatic Steatosis Through Regulation of the Sirt1/AMPK and Fatty Acid $\beta$-Oxidation Signaling Pathway in High-Fat Diet-Induced Obese Mice. Cell. Physiol. Biochem. 2018, 49, 1870-1884. [CrossRef]

46. Seok, J.; Jung, H.S.; Park, S.; Lee, J.O.; Kim, C.J.; Kim, G.J. Alteration of Fatty Acid Oxidation by Increased CPT1A on Replicative Senescence of Placenta-Derived Mesenchymal Stem Cells. Stem Cell Res. Ther. 2020, 11,1-13. [CrossRef]

47. Wang, Y.; Viscarra, J.; Kim, S.-J.; Sul, H.S. Transcriptional Regulation of Hepatic Lipogenesis. Nat. Rev. Mol. Cell Biol. 2015, 16, 678-689. [CrossRef]

48. Tian, X.; Ru, Q.; Xiong, Q.; Wen, R.; Chen, Y. Catalpol Attenuates Hepatic Steatosis by Regulating Lipid Metabolism via AMP-Activated Protein Kinase Activation. BioMed Res. Int. 2020, 2020, 6708061. [CrossRef]

49. Yuk, T.; Kim, Y.; Yang, J.; Sung, J.; Jeong, H.S.; Lee, J. Nobiletin Inhibits Hepatic Lipogenesis via Activation of AMP-Activated Protein Kinase. Evidence-Based Complement. Altern. Med. 2018, 2018, 7420265. [CrossRef]

50. Zhang, Y.; Meng, T.; Zuo, L.; Bei, Y.; Zhang, Q.; Su, Z.; Huang, Y.; Pang, J.; Xiang, Q.; Yang, H. Xyloketal B Attenuates Fatty Acid-Induced Lipid Accumulation via the SREBP-1c Pathway in NAFLD Models. Mar. Drugs 2017, 15, 163. [CrossRef] 
51. Varshney, R.; Gupta, S.; Roy, P. Cytoprotective Effect of Kaempferol Against Palmitic Acid-Induced Pancreatic $\beta$-Cell Death through Modulation of Autophagy via AMPK/MTOR Signaling Pathway. Mol. Cell. Endocrinol. 2017, 448, 1-20. [CrossRef]

52. Bauer, R.C.; Sasaki, M.; Cohen, D.M.; Cui, J.; Smith, M.A.; Yenilmez, B.O.; Steger, D.J.; Rader, D.J. Tribbles-1 Regulates Hepatic Lipogenesis through Posttranscriptional Regulation of C/EBP $\alpha$. J. Clin. Investig. 2015, 125, 3809-3818. [CrossRef]

53. Park, S.; Choi, Y.; Um, S.-J.; Yoon, S.K.; Park, T. Oleuropein Attenuates Hepatic Steatosis Induced by High-Fat Diet in Mice. J. Hepatol. 2011, 54, 984-993. [CrossRef]

54. Matsusue, K.; Gavrilova, O.; Lambert, G.; Brewer, H.B.; Ward, J.M.; Inoue, Y.; Leroith, D.; Gonzalez, F.J. Hepatic CCAAT/Enhancer Binding Protein $\alpha$ Mediates Induction of Lipogenesis and Regulation of Glucose Homeostasis in Leptin-Deficient Mice. Mol. Endocrinol. 2004, 18, 2751-2764. [CrossRef]

55. Cho, S.-J.; Jung, U.J.; Choi, M.-S. Differential Effects of Low-Dose Resveratrol on Adiposity and Hepatic Steatosis in Diet-Induced Obese Mice. Br. J. Nutr. 2012, 108, 2166-2175. [CrossRef]

56. Napal, L.; Marrero, P.F.; Haro, D. An Intronic Peroxisome Proliferator-Activated Receptor-Binding Sequence Mediates Fatty Acid Induction of the Human Carnitine Palmitoyltransferase 1A. J. Mol. Biol. 2005, 354, 751-759. [CrossRef] [PubMed]

57. Fontaine, M.; Dessein, A.-F.; Douillard, C.; Dobbelaere, D.; Brivet, M.; Boutron, A.; Zater, M.; Mention-Mulliez, K.; Martin-Ponthieu, A.; Vianey-Saban, C.; et al. A Novel Mutation in CPT1A Resulting in Hepatic CPT Deficiency. JIMD Reports 2012, 6, 7-14. [CrossRef] [PubMed]

58. Rafiei, H.; Omidian, K.; Bandy, B. Dietary Polyphenols Protect Against Oleic Acid-Induced Steatosis in an in Vitro Model of NAFLD by Modulating Lipid Metabolism and Improving Mitochondrial Function. Nutrients 2019, 11, 541. [CrossRef]

59. Parra-Vargas, M.; Sandoval-Rodríguez, A.; Rodriguez-Echevarria, R.; Dominguez-Rosales, J.A.; Santos-Garcia, A.; Armendáriz-Borunda, J. Delphinidin Ameliorates Hepatic Triglyceride Accumulation in Human HepG2 Cells, But Not in Diet-Induced Obese Mice. Nutrients 2018, 10, 1060. [CrossRef] [PubMed]

60. Brown, Z.J.; Fu, Q.; Ma, C.; Kruhlak, M.; Zhang, H.; Luo, J.; Heinrich, B.; Yu, S.J.; Zhang, Q.; Wilson, A.; et al. Carnitine Palmitoyltransferase Gene Upregulation by Linoleic Acid Induces CD4+ T Cell Apoptosis Promoting HCC Development. Cell Death Dis. 2018, 9, 620. [CrossRef]

61. Lin, C.-W.; Peng, Y.-J.; Lin, Y.-Y.; Mersmann, H.J.; Ding, S.T. LRRK2 Regulates CPT1A to Promote $\beta$-Oxidation in HepG2 Cells. Molecules 2020, 25, 4122. [CrossRef]

62. Blainski, A.; Lopes, G.C.; De Mello, J.C.P. Application and Analysis of the Folin Ciocalteu Method for the Determination of the Total Phenolic Content from Limonium Brasiliense, L. Molecules 2013, 18, 6852-6865. [CrossRef]

63. Fan, H.; Chen, Y.-Y.; Bei, W.-J.; Wang, L.-Y.; Chen, B.-T.; Guo, J. In VitroScreening for Antihepatic Steatosis Active Components Within Coptidis Rhizoma Alkaloids Extract Using Liver Cell Extraction With HPLC Analysis and a Free Fatty Acid-Induced Hepatic Steatosis HepG2 Cell Assay. Evid. Based Complement. Altern. Med. 2013, 2013, 459390. [CrossRef] [PubMed]

64. Shen, L.; Hillebrand, A.; Wang, D.Q.-H.; Liu, M. Isolation and Primary Culture of Rat Hepatic Cells. J. Vis. Exp. 2012, 10, 3791. [CrossRef] [PubMed]

Sample Availability: Samples of the compounds are not available from the authors.

Publisher's Note: MDPI stays neutral with regard to jurisdictional claims in published maps and institutional affiliations.

(C) 2020 by the authors. Licensee MDPI, Basel, Switzerland. This article is an open access article distributed under the terms and conditions of the Creative Commons Attribution (CC BY) license (http://creativecommons.org/licenses/by/4.0/). 